Provided for non-commercial research and education use. Not for reproduction, distribution or commercial use.

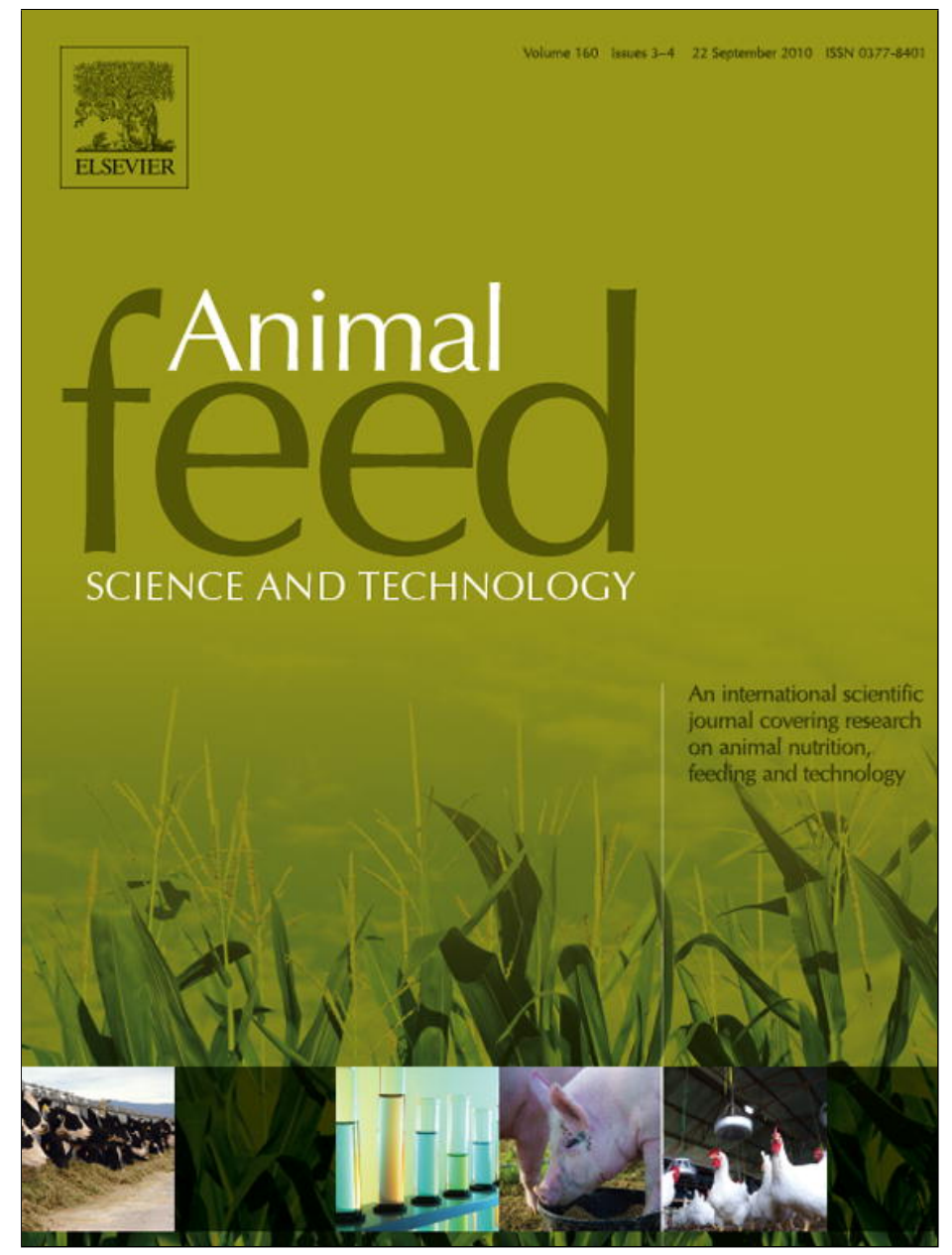

This article appeared in a journal published by Elsevier. The attached copy is furnished to the author for internal non-commercial research and education use, including for instruction at the authors institution and sharing with colleagues.

Other uses, including reproduction and distribution, or selling or licensing copies, or posting to personal, institutional or third party websites are prohibited.

In most cases authors are permitted to post their version of the article (e.g. in Word or Tex form) to their personal website or institutional repository. Authors requiring further information regarding Elsevier's archiving and manuscript policies are encouraged to visit:

http://www.elsevier.com/copyright 


\title{
In vitro ruminal fermentation kinetics and energy utilization of three Mexican tree fodder species during the rainy and dry period
}

\author{
L.M. Camacho a,b,c, R. Rojo a,*, A.Z.M. Salemª,b, G.D. Mendoza ${ }^{\text {c }}$, D. López ${ }^{\mathrm{a}}$, J.L. Tinoco ${ }^{\mathrm{a}}$, \\ B. Albarrán ${ }^{\mathrm{a}}$, O.D. Montañez-Valdez ${ }^{\mathrm{d}}$ \\ a Centro Universitario UAEM-Temascaltepec, Universidad Autónoma del Estado de México, Mexico \\ b Department of Animal Production, Faculty of Agriculture (El-Shatby), Alexandria University, Egypt \\ c Universidad Autónoma Metropolitana, Unidad Xochimilco, México, Calzada del Hueso 1100, D.F., C.P. 04970, Mexico \\ d Centro Universitario del Sur de la Universidad de Guadalajara (CUSUR-UDG), Mexico
}

\section{A R T I C L E I N F O}

\section{Article history:}

Received 9 May 2009

Received in revised form 27 May 2010

Accepted 27 July 2010

\section{Keywords:}

Browse

Cow

Dry season

Gas production

Goats

Rainy season

\section{A B S T R A C T}

A factorial experimental design $(3 \times 2 \times 3)$ was used to evaluate the effect of season of harvest and type of ruminal inoculums on in vitro ruminal fermentation kinetics and energy utilization of three browse tree foliages (Lysiloma acapulcencis, Quercus laeta and Pithecellobium dulce). Browse species were harvested during the dry season (DS) and rainy season (RS) and incubated with three different ruminal inoculums: cow, goats previously adapted (AG) or not adapted (UG) to browse species fed in their daily diet. Chemical composition, total condensed tannin (TCT), free-condensed tannin (free-CT), protein-bound condensed tannin (PCT), fiber-bound condensed tannin (FCT) as well as in vitro assaying of ruminal gas production kinetics was determined, while the short chain fatty acids (SCFA) and metabolizable energy (ME) were estimated. Crude protein (CP) was considerably higher (season $\times$ browse; $\mathrm{P}<0.001$ ) during RS. P. dulce had the lowest neutral detergent fiber (NDFom) and acid detergent fiber (ADFom) in both seasons, while L. acapulcencis had the highest values and $Q$. laeta values were intermediate, with an overall increase in fiber fractions in DS browse foliages (season $\times$ browse; $\mathrm{P}<0.001$ ). TCT content in tree species revealed differences $(\mathrm{P}<0.01)$. FCT and PCT were lower in $Q$. laeta and $P$. dulce during the RS than in DS, lower $(\mathrm{P}<0.01)$ Free-CT fractions were observed in L. acapulcencis and $Q$. Laeta than in $P$. dulce, during both seasons. in vitro gas production parameters was increased $(\mathrm{P}<0.05)$ in DS than in RS in browses with low and medium tannins contents (i.e., P. dulce and Q. laeta); consequently, browses energy utilization (i.e., SCFA and ME) and organic matter degradability (OMD) as well as fermentation efficiency (i.e., partition factor; PF) were improved $(\mathrm{P}<0.05)$. Generally, $P$. dulce had the highest $(\mathrm{P}<0.001)$ ruminal fermentation parameters and energy utilization values (more in DS than RS), while lowest values were founded in $L$. acapulcencis. Ruminal fluid of AD and UG had higher $(\mathrm{P}<0.001)$ browse ruminal fermentation kinetics, efficiency and energy utilization than cow's rumen fluid. The browse fermentation and energy utilization was improved in DS versus in RS and the browse fermentation and utilization were highest $(\mathrm{P}<0.05)$ in AG ruminal fluid than the others. Our results suggested a better nutritive value of $P$. dulce and $Q$. laeta with low and medium tannins contents and high CP concentration in cows and goats during the DS. Goats previously fed browse species in diets had a better ability to degrade and ferment the browse species than other animals. Crown Copyright @ 2010 Published by Elsevier B.V. All rights reserved.

Abbreviations: AG, adapted goats; AOAC, Association of Official Analytical Chemists; DM, dry matter; OMD, organic matter degradability; DS, dry season; $\mathrm{GP}$, in vitro gas production; RS, rainy season; UG, unadapted goats; ADFom, acid detergent fiber; NDFom, neutral detergent fiber; CP, crude protein; TCT, total condensed tannins; Free-CT, free-condensed tannins; PCT, protein-bound condensed tannins; FCT, fiber-bound condensed tannins.

* Corresponding author at: Centro Universitario UAEM-Temascaltepec, Universidad Autónoma del Estado de México, Mexico.

Tel.: +52 7162665138; fax: +52 7162665209.

E-mail address: dr_rojo70@yahoo.com.mx (R. Rojo). 


\section{Introduction}

Browse tree fodders could play an important role as a source of nutrients to feed grazing small ruminants under the extensive livestock production systems (Norton, 2000; Salem et al., 2006). Shrub legumes have been considered a promising option due to their rapid growth, provided high-protein content and good drought tolerance (Paterson et al., 1998) that could be also used to supplement low protein feeds (Leng, 1997; Salem et al., 2006). Unfortunately, many tropical tree fodders and shrub legumes contain high concentrations of secondary compounds, particularly tannins (Salem et al., 2006; Mbugua et al., 2008) that can be reacting negatively with others nutrients (Mangan, 1988) and could be have detrimental or beneficial effects on animal nutrition (Waghorn and McNabb, 2003; Mbugua et al., 2008). Although the digestive tract of goats is anatomically similar to that of sheep and cows, goats have a large physiological capacity to adapt to high tannin levels in the diet. In vivo and in vitro studies conducted revealed that goats are more efficient than sheep digesting feedstuffs with low nitrogen, high fiber or high tannin contents of tree fodders and shrubs (Salem et al., 2006; Tefera et al., 2008). There are some comparative studies in the in vitro digestibility and fermentability of forages using sheep, goats and cow's rumen fluid as inoculums sources, but few comparisons between cows and goat have been reported up to date (Calabró et al., 2004; Mould et al., 2005; Salem, 2005).

In vitro ruminal evaluations of such browse fodders should not only be based on in vitro gas production kinetics because partitions of energy released from degraded substrate contribute both to short chain fatty acids (SCFA) production and for microbial protein synthesis (Blümmel et al., 1994). The concept of partitioning of fermentation products (partitioning factor; PF) was introduced recently to express the conversion of energy from truly degraded substrate required to yield $1 \mathrm{ml}$ of gas (Blümmel et al., 1997). The effect of tannins on PF values of browse plants has not been extensively investigated. This is largely due to the difficulty in quantifying the amount of substrate degraded in vitro. It is important to determine the PF values for browse plants because most of these plants contain condensed tannins, which may cause harmful effects on rumen microbial fermentation such as reduces the VFA concentration and ruminal microorganisms toxicity (Jones et al., 1994).

This study was aimed to investigate interspecies differences among three tree fodders species of different tannins levels along the two seasonal periods of Mexico (i.e., rainy and dry) using rumen fluid from goats and cows as inoculums donor to determine in vitro fermentation of gas production kinetics and energy utilization.

\section{Materials and methods}

\subsection{Area of sample collection}

Tree fodder species were collected from the South of Estado de México (Tejupilco). Geographically, this is located at $19^{\circ} 02^{\prime} 04^{\prime \prime}$ north latitude and $100^{\circ} 02^{\prime} 14^{\prime \prime}$ west longitude at an elevation of 1720 masl. The climate is moderately humid with an average temperature of $15-18^{\circ} \mathrm{C}$ and annual rainfall of $950-1000 \mathrm{~mm}$ (García, 1987) and the related metabolic work and laboratory analyses were completed at the Centro Universitario UAEM Temascaltepec located in the municipality of Temascaltepec de González Estado de México.

\subsection{Browse species}

We sampled a mixture of young and mature leaves from three browses species - Tepehuaje (Lysiloma acapulcencis), Encino prieto (Quercus laeta) and Pinzán (Pithecellobium dulce) - that contain different levels of CT (high, medium and low) from several locations in the South of Estado de México. Three individual samples ( $\sim 5 \mathrm{~kg}$, each one pooled of at least 7 trees) were randomly collected at different sampling time, for each browse species during the rainy (i.e., August/September, 2006) and/or dry (April/May, 2007) seasons. These samples were air dried in the shade to minimize changes in tannins content and activity (Makkar and Singh, 1991; Yousef and Rouzbehan, 2008; Robinson et al., 2006).

\subsection{Analytical methods}

Fresh samples were dried at $45^{\circ} \mathrm{C}$ for $48 \mathrm{~h}$ for moisture determination and ground in a Willey-mill to pass a one mm screen. Ground samples were analyzed for dry matter (DM) by drying at $105^{\circ} \mathrm{C}$ for $24 \mathrm{~h}$ in a forced air oven. Ash content was measured after igniting samples in a muffle furnace at $550^{\circ} \mathrm{C}$ for $4 \mathrm{~h}$. The CP was determined by a Kjeldahl method (AOAC, 1990; ID 954.01). Neutral detergent fiber (NDFom) and acid detergent fiber (ADFom) were determined by methods of Van Soest et al. (1991) with NDFom assayed without use of an alpha amylase, but with sodium sulfite. Both NDFom and ADFom are expressed without residual ash. Total condensed tannins (TCTs) were assayed using the butanol-HCl method (Terrill et al., 1992), modified by López et al. (2004), as internal standards using L. acapulcencis. Analyses of the free (free-CT), proteinbound (PCT) and fiber-bound (FCT) condensed tannins were conducted, according to the method of Porter et al. (1986). The purification was performed with Sephadex LH-20 as described by Asquith and Butler (1985) with modifications by Hedqvist et al. (2000). Tannin results were the starting point for categorizing the species in three types: high (L. acapulcencis), medium (Q. laeta) and low (P. dulce) tannin concentration (Table 1). 
Table 1

Chemical composition and condensed tannins ( $\mathrm{g} / \mathrm{kg} \mathrm{DM})$, of the leaves of three species of browse tree during the rainy and dry seasons.

\begin{tabular}{|c|c|c|c|c|c|c|c|c|c|c|}
\hline \multirow{2}{*}{$\begin{array}{l}\text { Season }(S) \\
\text { Browse }(B)\end{array}$} & \multicolumn{3}{|l|}{ Rainy } & \multicolumn{3}{|l|}{ Dry } & \multirow[t]{2}{*}{ Sed } & \multicolumn{3}{|l|}{ P value } \\
\hline & L. acapulcencis. & Q. laeta. & P. dulce & L. acapulcencis. & Q. laeta & P. dulce. & & $S$ & $B$ & $S \times B$ \\
\hline $\mathrm{OM}$ & $945.9^{\mathrm{b}}$ & $950.4^{\mathrm{a}}$ & $909.6^{d}$ & $941.8^{c}$ & $906.4^{\mathrm{e}}$ & $862.9^{f}$ & 0.79 & $<0.001$ & $<0.001$ & $<0.001$ \\
\hline $\mathrm{CP}$ & $177.0^{c}$ & $94.1^{\mathrm{e}}$ & $261.5^{\mathrm{a}}$ & $110.6^{d}$ & $84.7^{f}$ & $187.8^{\mathrm{b}}$ & 0.09 & $<0.001$ & $<0.001$ & $<0.001$ \\
\hline NDFom & $607.3^{a}$ & $584.1^{\mathrm{ab}}$ & $495.8^{c}$ & $545.0^{\mathrm{b}}$ & $408.3^{d}$ & $357.3^{e}$ & 2.06 & $<0.001$ & $<0.001$ & $<0.001$ \\
\hline ADFom & $500.8^{a}$ & $411.8^{b}$ & $365.7^{c}$ & $478.6^{a}$ & $249.8^{d}$ & $274.7^{d}$ & 2.31 & $<0.001$ & $<0.001$ & $<0.001$ \\
\hline Free-CT & $116.3^{\mathrm{a}}$ & $64.2^{\mathrm{cd}}$ & $36.6^{d}$ & $101.6^{\mathrm{ab}}$ & $80.2^{\mathrm{bc}}$ & $68.3^{\mathrm{cd}}$ & 6.71 & 0.077 & $<0.001$ & 0.016 \\
\hline FCT & $3.7^{b}$ & $2.7^{c}$ & $4.1^{\mathrm{ab}}$ & $2.8^{\mathrm{c}}$ & $2.5^{\mathrm{c}}$ & $4.7^{\mathrm{a}}$ & 0.21 & 0.19 & $<0.001$ & 0.003 \\
\hline TCT & $187.8^{a}$ & $89.9^{\mathrm{bc}}$ & $62.6^{c}$ & $160.2^{\mathrm{a}}$ & $109.0^{\mathrm{b}}$ & $94.1^{\mathrm{bc}}$ & 10.77 & 0.229 & $<0.001$ & $<0.01$ \\
\hline
\end{tabular}

Means with different superscripts within a row differ $(\mathrm{P}<0.05)$ between season of harvest of browse species. OM: organic matter, CP: crude protein, NDFom: neutral detergent fiber, ADFom: acid detergent fiber, Free-CT: free-condensed tannins, PCT: protein-bound condensed tannins, FCT: fiber-bound condensed tannins, TCT: total condensed tannins and Sed: standard error of the difference.

\subsection{In vitro ruminal gas production}

\subsubsection{Donor species}

Rumen fluid for the in vitro gas production of the tree fodder species of each growing season was withdrawn before the morning feed from goats and cows which have the following characterizations and feeding strategies: Two brown Swiss American cows ( $530 \pm 5.0 \mathrm{~kg}$ body weight) and four males Criollo $\times$ Nubian goats ( $34 \pm 3.0 \mathrm{~kg}$ body weight) were used as sources of rumen inoculum. Animals were fitted with permanent ruminal cannula about 150 days before use as donor of ruminal inoculums. The two cows and two goats (unadapted goats; UG) were fed forage:concentrate (80:20; DM basis) diets. The forage contained a mixture of alfalfa hay $(400 \mathrm{~g} / \mathrm{kg})$, corn silage $(400 \mathrm{~g} / \mathrm{kg})$ and corn straw $(200 \mathrm{~g} / \mathrm{kg})$ with a concentrate mixture (220 g kg CP), containing ground sorghum (380 g/ kg), corn (380 g/ $/ \mathrm{kg})$, soybean ( $120 \mathrm{~g} / \mathrm{kg}), \mathrm{molasses}(80 \mathrm{~g} / \mathrm{kg}), \mathrm{urea}$ $(20 \mathrm{~g} / \mathrm{kg})$ and minerals $(20 \mathrm{~g} / \mathrm{kg})$. The other two goats were fed with the same concentrate mixture offered to the cows and UG, but the forage proportions was alfalfa hay $(300 \mathrm{~g} / \mathrm{kg})$ and mixture of browse species $(700 \mathrm{~g} / \mathrm{kg}) \mathrm{composed} \mathrm{of} 128 \mathrm{~g} / \mathrm{kg}$ P. dulce, $197.6 \mathrm{~g} / \mathrm{kg}$ Quercus sp., $261 \mathrm{~g} / \mathrm{kg}$ Q. laeta, $413.8 \mathrm{~g} / \mathrm{kg}$ L. acapulcencis. The AG was fed this diet for 100 days before sample incubation. All animal groups were fed twice daily at 07:00 and 16:00 h. All animals had free access to vitamin-mineral mixture and clean water.

\subsubsection{Rumen liquor sampling, handling and in vitro incubations}

Ruminal fermentation activity was assessed in vitro using the reading pressure technique (RPT; DELTA OHM, Italy) of Theodorou et al. (1994) with the modification of Mauricio et al. (1999). Rumen fluid was collected at $07.00 \mathrm{~h}$ prior to feeding of donors animals (Cows, AG or UG) described and mentioned above. Rumen digesta was collected from multiple sites within the rumen of each animal group separately in pre-warmed thermos flasks and hand-squeezed, with the assistance of a portable bomb (BARNANT COMPANY, USA) and transported immediately to the laboratory. Rumen contents of each animal species was strained through four layers of cheesecloth, and kept at $39{ }^{\circ} \mathrm{C}$ under a $\mathrm{CO}_{2}$ atmosphere.

Approximately one gram of browse tree sample was weighed into $160 \mathrm{ml}$ serum bottles. Using an automatic dispenser (Jencons, Hemel Hemstead, England), $90 \mathrm{ml}$ reduced RPT buffer containing micro- and macro-elements, a reducing agent and a reduction indicator of resazurin, was transferred to each serum bottle. Serum bottles without samples (i.e., blanks) were also included to allow correction of $96 \mathrm{~h}$ degradability values for residual feed from rumen fluid and three bottles of blank (containing only rumen fluid inoculum were incubated as blanks and used to compensate for gas production in the absence of substrate) and three samples of alfalfa as slandered were incubated each run.

After addition of buffer, the flasks were sealed and stored at $39^{\circ} \mathrm{C}, 8 \mathrm{~h}$ before inoculation with rumen fluid before being transferred into the incubators (Binder-Incubator, Binder Company, Germany) to confirm the color that assures the suitable anaerobic conditions. Ten $\mathrm{ml}$ of rumen fluid were added to each serum bottles (previously prepared to contain $90 \mathrm{ml}$ of buffer and one gram of browse sample) and incubated at $39^{\circ} \mathrm{C}$ for the $96 \mathrm{~h}$ duration of the experiment. Once filled up, all the bottles were closed with rubber stoppers, crimped with aluminum seals, shaken and placed in the incubator at $39{ }^{\circ} \mathrm{C}$. Volume of gas produced was recorded at several incubation times $(2,4,6,8,10,12,16,20,24,48,72$ and 96 h after inoculation time), using the RPT. Inoculation was complete within $60 \mathrm{~min}$ of fluid being prepared and during this time, anaerobic conditions were maintained through constant flushing of rumen fluid containers and serum bottles with carbon dioxide gas. The time between rumen fluid collection and the start of inoculation was about $40 \mathrm{~min}$. Fermentation flasks without samples (i.e., blanks) were included to allow correction for gas produced directly from rumen fluid. Browse leaves were incubated in quadruplicate. Volume of gas ( $\mathrm{ml} / \mathrm{g} \mathrm{DM}$ ) produced after $24 \mathrm{~h}$ of incubation (GP24) was used as an index of energy feed value of tree fodder samples.

\subsubsection{Estimation of truly degraded substrate}

At the end of incubation (i.e., $96 \mathrm{~h}$ ), the contents of each serum bottle were filtered using sintered glass crucibles (coarse porosity no. 1 , pore size $\mu \mathrm{m}$ porosity, Pyrex, Stone, UK) under vacuum. Fermentation residues were dried at $105^{\circ} \mathrm{C}$ overnight 
to estimate the potential DM disappearance and then incinerated in a muffle furnace at $550{ }^{\circ} \mathrm{C}$ for $12 \mathrm{~h}$. Loss in weight after incineration was used as a measure of undegradable OM. The organic matter digestibility at $96 \mathrm{~h}$ of incubation (OMD96; $\mathrm{g} / \mathrm{kg} \mathrm{DM}$ ) was calculated as the difference between OM content of substrate and its undegradable OM.

\subsection{Calculations}

The pressure generated by the gas accumulated in the upper part of the incubation flasks was measured through a pressure transducer connected to a digital reader. The equation was previously obtained using PROC REG of the SAS program: $Y=0.0854+(5.2869 \times X)$, where $Y$ is volume $(\mathrm{ml}), X$ is pressure $(\mathrm{psi}) \cdot R^{2}=0.99$. Then gas production data $(\mathrm{ml} / \mathrm{g} \mathrm{DM}) \mathrm{were}$ fitted using the NLIN option of SAS (2002) to the model of France et al. (2000) as

$$
A=b \times\left(1-e^{-c(t-L)}\right)
$$

where $A$ is the volume of gas production at time $t ; b$ the asymptotic gas production ( $\mathrm{ml} / \mathrm{g} \mathrm{DM}) ; c$ is the rate of gas production (/h) from the slowly fermentable feed fraction $b$, and $L$ is the discrete lag time prior to gas production.

Metabolizable energy (ME, MJ/kg DM) was estimated according to Menke and Steingass (1988) as

$$
\mathrm{ME}(\mathrm{MJ} / \mathrm{kg} \quad \mathrm{DM})=2.20+0.136 \mathrm{GP} 24(\mathrm{ml} / 0.2 \mathrm{~g} \quad \mathrm{DM})+0.057 \mathrm{CP}
$$

where GP24 was $24 \mathrm{~h}$ gas volume and CP (\% DM) was that of the tree leaves.

Short chain fatty acids (SCFA) were estimated depending on the relationship $\left(R^{2}=0.94\right)$ between gas production at $24 \mathrm{~h}$ and SCFA concentration of tannin-containing browses following the equation of Getachew et al. (2002):

$$
\mathrm{mmolSCFA}=-0.00425+0.0222 \mathrm{GP} 24(\mathrm{ml} / 0.2 \mathrm{~g} \text { DM) }
$$

Partitioning factors (PF, used as a measure of fermentation efficiency) were calculated as the relating OM degradation to total gas production at $96 \mathrm{~h}$ (i.e., OM disappearance (OMD96)/total gas production (GP96); Blümmel et al., 1997).

\subsection{Experimental design and statistical analysis}

Data for the chemical assays were analyzed using the general linear model (GLM) procedure in SAS (2002) for a completely randomized design with two seasons (rainy and dry) $\times$ three browse species in a factorial arrangement with three repetitions (Steel and Torrie, 1980). Means were tested using a least square means test (LSMEANS) with the statistical model:

$$
Y_{j k}=\mu+S_{j}+B_{k}+S_{j} \times B_{k}+E_{j k}
$$

where $Y_{i j k}$ represents response variables (chemical composition) for the two seasons $(j$ ) for each of the three browse species $(k) ; \mu=$ general mean; $S_{j}=$ effect of $j$-season; $B_{k}=$ effect of $k$ browse species; $S_{j} \times B_{k}=$ interaction of the $j$ season with $k$ browse species; $E_{j k}=$ the error term $-\mathrm{NI}\left(0, \sigma^{2}\right)$.

Data for in vitro ruminal fermentation kinetics and energy utilization were analyzed using a randomized complete block design with two seasons (rainy and dry) $\times$ three sources of inoculum (cows, UG, and AG) $\times 3$ browse species in factorial arrangement with three repetitions (Steel and Torrie, 1980). The mixed model was:

$$
Y_{j k l}=\mu+S_{j}+T I_{k}+S p_{l}+\beta n+S_{j} \times T I_{k} \times S p_{l}+E_{j k l}
$$

where $Y_{j k l}$ represents response variables (ruminal fermentation activity, energy utilization of metabolizable energy and short chain fatty acids) for the same season $(j)$, source of ruminal inoculum $(k)$, and browse species $(l) ; \mu=$ general mean; $S_{j}=$ effect of $j$ season; $T I_{k}=$ effect of $k$ type of ruminal inoculum; $S p_{l}=$ effect of $l$ browse species; $\beta n=$ effect of $n$-block (repeated incubation); $S_{j} \times T I_{k} \times S p_{l}=$ interaction of the $j$ season with $k$ type of ruminal inoculum and $l$ browse species; $E_{j k l}=$ the error term -NI $\left(0, \sigma^{2}\right)$.

Differences among means with $\mathrm{P}<0.05$, determined using a least square means test (LSMEANS), were accepted as representing statistically significant differences (Steel and Torrie, 1980).

Correlation coefficients between tree fodders chemical and condensed tannins contents with the rumen fermentation parameters of gas production and energy were estimated using the CORR option of SAS (2002). Relationships between the animal species in fermentation of tree fodders were also estimated.

\section{Results}

\subsection{Chemical composition and condensed tannins fractions of the tree leaves}

Crude protein (i.e., CP) content of the browse species ranged from 85 (DS: dry season) and 94 in Q. Laeta (RS: rainy season) to $262 \mathrm{~g} / \mathrm{kg}$ DM (P. dulce) in RS (Table 1 ). Other browse species had intermediate values during the two growing seasons. Overall, CP of browse species was considerably higher in the RS (season $\times$ browse; $\mathrm{P}<0.001$ ). P. dulce had the lowest NDFom and ADFom in the two seasons, L. acapulcencis had the highest values, and $Q$. laeta were intermediate with an overall increase in fiber fractions in browse foliages in the RS (season $\times$ browse; $\mathrm{P}<0.001$ ). Soluble or free-CT fraction varied from 36.6 in $P$. 
Table 2

In vitro ruminal fermentation kinetics of gas production at $96 \mathrm{~h}$ of incubation ( $\mathrm{ml} / \mathrm{g} \mathrm{DM})$, gas production parameters $(b, c$ and $L$ ), energy utilization (ME and SCFA), OMD96, and the efficiency of fermentation (PF) of some browse tree foliages incubated with ruminal fluid from cows, unadapted (UG) and adapted (AG) goats during the rainy and dry seasons.

\begin{tabular}{|c|c|c|c|c|c|c|c|c|c|c|}
\hline Season & Inoculum & Browse & GP96 & $b$ & c & $L$ & SCFA & ME & OMD96 & $\mathrm{PF}$ \\
\hline \multirow[t]{9}{*}{ Rainy } & \multirow[t]{3}{*}{ Cows } & L. acapulcencis & $45.65^{\mathrm{i}}$ & $44.97^{j}$ & $0.023^{\text {de }}$ & $1.78^{\text {cdef }}$ & $0.08^{\mathrm{kl}}$ & $3.34^{\mathrm{i}}$ & $159.66^{g}$ & $4.24^{b}$ \\
\hline & & Q. laeta & $128.48^{\text {ef }}$ & $133.01^{f}$ & $0.011^{\mathrm{g}}$ & $3.62^{\mathrm{b}}$ & $0.10^{\mathrm{kj}}$ & $3.43^{\mathrm{i}}$ & $224.73^{f}$ & $2.91^{\text {defg }}$ \\
\hline & & P. dulce & $123.31^{\mathrm{f}}$ & $134.59^{f}$ & $0.036^{c}$ & $2.43^{\mathrm{bcd}}$ & $0.33^{e}$ & $5.42^{e}$ & $402.38^{d}$ & $3.37^{\text {cde }}$ \\
\hline & \multirow[t]{3}{*}{ UG } & L. acapulcencis & $84.38^{g}$ & $82.16^{\mathrm{g}}$ & $0.014^{\mathrm{fg}}$ & $0.00^{\mathrm{g}}$ & $0.10^{\mathrm{jk}}$ & $3.50^{\mathrm{i}}$ & $96.85^{\mathrm{i}}$ & $1.51^{\mathrm{j}}$ \\
\hline & & Q. laeta & $135.29^{\text {de }}$ & $135.60^{f}$ & $0.026^{d}$ & $0.10^{\text {fg }}$ & $0.27^{f}$ & $4.45^{\mathrm{f}}$ & $242.11^{\text {ef }}$ & $1.96^{\mathrm{ij}}$ \\
\hline & & P. dulce & $155.25^{c}$ & $158.07^{d}$ & $0.040^{\mathrm{bc}}$ & $0.45^{\mathrm{efg}}$ & $0.41^{\mathrm{cd}}$ & $5.92^{\mathrm{cd}}$ & $399.65^{d}$ & $2.59^{\text {fghi }}$ \\
\hline & \multirow[t]{3}{*}{ AG } & L. acapulcencis & $78.40^{\mathrm{g}}$ & $81.02^{\mathrm{g}}$ & $0.024^{\mathrm{de}}$ & $1.40^{\text {cdefg }}$ & $0.15^{\text {hi }}$ & $3.78^{\mathrm{h}}$ & $167.53^{\mathrm{g}}$ & $2.41^{\text {ghi }}$ \\
\hline & & Q. laeta & $122.24^{\mathrm{f}}$ & $129.21^{\mathrm{f}}$ & $0.021^{\mathrm{de}}$ & $2.58^{\mathrm{bc}}$ & $0.21^{\mathrm{g}}$ & $4.10^{g}$ & $250.61^{e}$ & $2.44^{\mathrm{ghi}}$ \\
\hline & & P. dulce & $155.60^{c}$ & $161.98^{\mathrm{cd}}$ & $0.039^{\mathrm{bc}}$ & $1.03^{\text {cdefg }}$ & $0.43^{\mathrm{cd}}$ & $6.06^{c}$ & $437.56^{c}$ & $2.86^{\text {defg }}$ \\
\hline \multirow[t]{9}{*}{ Dry } & \multirow[t]{3}{*}{ Cows } & L. acapulcencis & $38.69^{i}$ & $43.05^{j}$ & $0.019^{\text {ef }}$ & $5.65^{a}$ & $0.05^{1}$ & $3.04^{j}$ & $218.75^{f}$ & $7.13^{a}$ \\
\hline & & Q. laeta & $140.78^{d}$ & $146.17^{e}$ & $0.020^{\text {def }}$ & $1.88^{\text {bcde }}$ & $0.2^{\mathrm{g}}$ & $4.04^{g}$ & $401.24^{d}$ & $3.38^{\text {cde }}$ \\
\hline & & P. dulce & $151.51^{\mathrm{c}}$ & $156.77^{d}$ & $0.037^{c}$ & $0.93^{\text {cdefg }}$ & $0.40^{\mathrm{d}}$ & $5.83^{d}$ & $543.79^{b}$ & $3.61^{b c}$ \\
\hline & \multirow[t]{3}{*}{ UG } & L. acapulcencis & $58.50^{\mathrm{h}}$ & $54.68^{\mathrm{i}}$ & $0.035^{\mathrm{c}}$ & $0.00^{\mathrm{g}}$ & $0.13^{\mathrm{ij}}$ & $3.54^{\mathrm{i}}$ & $126.09^{\mathrm{h}}$ & $2.16^{\mathrm{hi}}$ \\
\hline & & Q. laeta & $166.19^{b}$ & $167.01^{\mathrm{bc}}$ & $0.040^{\mathrm{bc}}$ & $0.13^{\text {efg }}$ & $0.44^{\mathrm{c}}$ & $5.36^{\mathrm{e}}$ & $404.99^{d}$ & $2.50^{\text {ghi }}$ \\
\hline & & P. dulce & $180.32^{\mathrm{a}}$ & $179.05^{a}$ & $0.052^{\mathrm{a}}$ & $0.00^{g}$ & $0.55^{\mathrm{a}}$ & $6.71^{\mathrm{a}}$ & $543.48^{\mathrm{b}}$ & $2.96^{\text {defg }}$ \\
\hline & \multirow[t]{3}{*}{ AG } & L. acapulcencis & $65.31^{\mathrm{h}}$ & $64.27^{\mathrm{h}}$ & $0.039^{b c}$ & $0.00^{\mathrm{g}}$ & $0.17^{\mathrm{h}}$ & $3.80^{\mathrm{h}}$ & $226.19^{\text {ef }}$ & $3.46^{\mathrm{cd}}$ \\
\hline & & Q. laeta & $170.46^{b}$ & $174.60^{\mathrm{ab}}$ & $0.036^{c}$ & $0.68^{\text {defg }}$ & $0.43^{\mathrm{cd}}$ & $5.28^{e}$ & $454.51^{\mathrm{c}}$ & $2.78^{\text {efgh }}$ \\
\hline & & P. dulce & $178.87^{a}$ & $181.78^{a}$ & $0.043^{b}$ & $0.38^{\text {efg }}$ & $0.51^{\mathrm{b}}$ & $6.47^{\mathrm{b}}$ & $576.20^{\mathrm{a}}$ & $3.18^{\text {cdef }}$ \\
\hline Sed & & & 1.59 & 1.58 & 0.001 & 0.37 & 0.007 & 0.04 & 4.88 & 0.14 \\
\hline \multicolumn{11}{|l|}{ P value } \\
\hline Season & & & $<0.001$ & $<0.001$ & $<0.001$ & 0.013 & $<0.001$ & $<0.001$ & $<0.001$ & $<0.001$ \\
\hline Inoculum & & & $<0.001$ & $<0.001$ & $<0.001$ & $<0.001$ & $<0.001$ & $<0.001$ & $<0.001$ & $<0.001$ \\
\hline Browse & & & $<0.001$ & $<0.001$ & $<0.001$ & 0.002 & $<0.001$ & $<0.001$ & $<0.001$ & $<0.001$ \\
\hline Season $\times$ Inoculum $\times$ Browse & & & $<0.001$ & $<0.001$ & $<0.001$ & $<0.001$ & $<0.001$ & $<0.001$ & $<0.001$ & $<0.001$ \\
\hline
\end{tabular}

Means within a column with different superscripts differ (P<0.05). Sed: Standard error of the difference. UG: unadapted goats, AG: adapted goats, GP96: cumulative gas production at $96 \mathrm{~h} ; b$ : asymptotic gas production ( $\mathrm{ml} / \mathrm{g} \mathrm{DM}) ; c$ : fractional rate of gas production (h $\left.{ }^{-1}\right) ; L$ : lag time (h); SCFA: short chain fatty acid concentration (mmol); ME: metablizable energy content (MJ/kg DM); OMD96: truly organic matter disappearance at $96 \mathrm{~h}$ (g/kg DM); PF: partitioning factor (OM disappearance (OMD96)/total gas production (GP96).

dulce to $116.3 \mathrm{~g} / \mathrm{kg}$ DM in L. acapulcencis during the rainy season. Protein-bound CT (PCT) fraction had the same trend of free-CT contents in tree species and varied $(\mathrm{P}<0.05)$ from 21 in P. dulce (in RS and DS) to 67.8 g/kg DM in L. acapulcencis (in RS). L. acapulcencis and Q. Laeta had lower $(\mathrm{P}<0.01)$ fiber-bound CT fractions than the P. dulce during the two seasons. $L$. acapulcencis had the highest $(\mathrm{P}<0.001)$ values of TCT ( 188 and $160 \mathrm{~g} / \mathrm{kg}$ DM during the DS and RS, respectively), while lowest values were in $P$. dulce (63 $\mathrm{g} / \mathrm{kg}$ DM in RS).

\subsubsection{In vitro fermentation and energy utilization of the tree leaves}

Gas production parameters (cumulative gas production after $96 \mathrm{~h}$ (GP96), potential gas production (asymptotic gas production; fraction $b$ ), and rate of gas production (fraction $c$ )) were greater $(\mathrm{P}<0.05)$ in DS than in RS browses of low and medium tannins contents (i.e., P. dulce and Q. laeta), with the exception of L. acapulcencis of the high tannins contents (Table 2). This effect was associated with a short discrete time lag (i.e., L). Consequently, browses energy utilization (i.e., SCFA and ME) and OMD as well as fermentation efficiency (i.e., partitioning factor; $\mathrm{PF}$ ) were improved $(\mathrm{P}<0.05)$ showing the same trend in $\mathrm{DS}$ than in RS browses.

Goat's rumen fluid had higher $(\mathrm{P}<0.001)$ browse ruminal gas production and energy utilization than cow's rumen fluid. Browses nutritive value (i.e. gas production and energy utilization) in goats previously exposed to the same browse species (i.e., AG), was higher $(\mathrm{P}<0.001)$ than in cows or UG. Goat's rumen fluid produced more gas earlier in the incubation than did cow's rumen fluid with a high differences by the end of the incubation between the two inocula (Figs. 1 and 2). Adapted goat's rumen fluid (i.e., AG) produced a highest volume of browses gas production than UG or cows during the two growing seasons. Rate of gas production profiles showed in Figs. 1 and 2, had the highest rate values with leaves from $P$. dulce, while L. acapulcencis leaves had the lowest rate and longer time of lag (i.e., $L$ ) during the fermentation.

In vitro gas production, energy parameters (SCFA and ME), and fermentation efficiency (i.e., PF) of browse in rumen fluid of cows and goats (Table 3 ) were positively correlated with browse $\mathrm{CP}$ concentration and negatively correlated with and negatively correlated $(\mathrm{P}<0.05)$ with the fiber fractions (i.e., NDFom and ADFom) and condensed tannins levels (TCT, free-CT, PCT and FCT). Only in AG, no correlations were observed between these secondary compounds and fiber fractions with browses $L$ and PF during the fermentation dynamics; as well as fiber-bound condensed tannins (FCT). Within each browse species, negative relationship (Table 4) was observed between fiber fractions and condensed tannins with ruminal gas production and energy utilization of browse species in the rumen fluid of cows and goats, although in some cases of CP, NDFom, and ADFom were not correlated with the rate of gas production of $P$. dulce. 


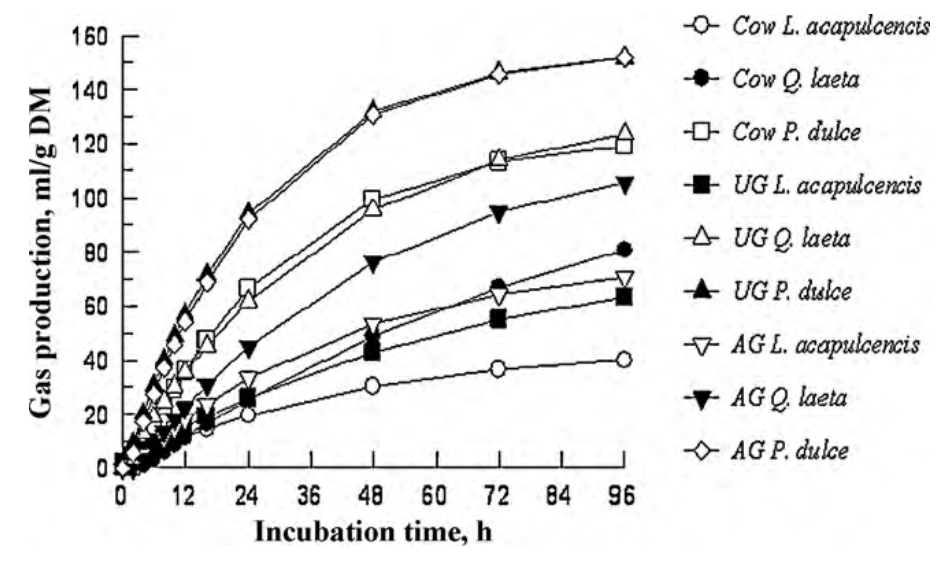

Fig. 1. Cumulative gas production profiles (ml gas/g DM) from in vitro fermentation of cow, unadapted goat (UA) and adapted goat (AG) rumen liquor during the rainy season of $L$. acapulcencis, Q. laeta and $P$. dulce leaves.

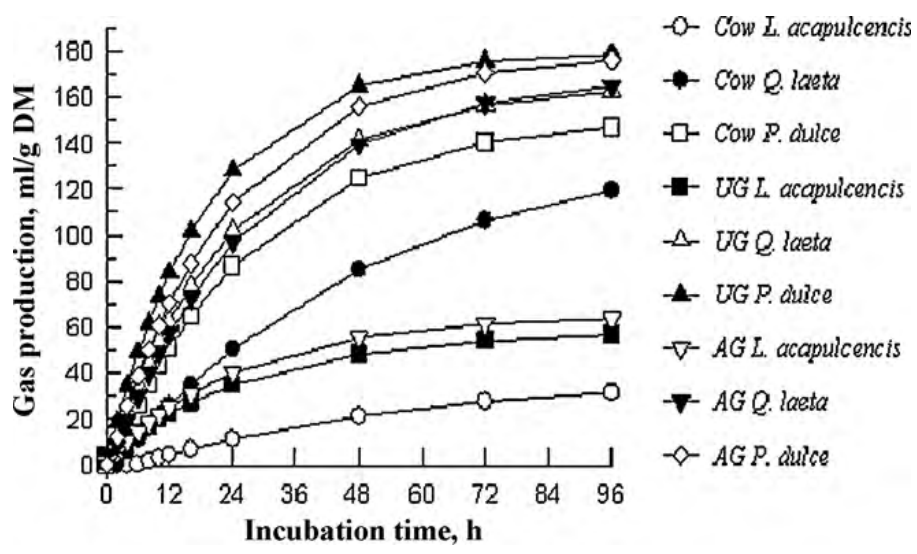

Fig. 2. Cumulative gas production profiles ( $\mathrm{ml}$ gas/g DM) from in vitro fermentation of cow, unadapted goat (UA), adapted goat (AG) rumen liquor during the dry season of L. acapulcencis, Q. laeta and P. dulce leaves.

\section{Discussion}

\subsection{Chemical composition and condensed tannins fractions of the tree leaves}

The lower CP content of browse species in the DS versus the RS is consistent with other studies, as was the observation that the minimum CP content of fodder tree leaves in the DS was more than twice that of grasses in the RS (Skarpe and Bergström, 1986; Evitayani et al., 2004). The low CP value recorded during the DS is thus presumably related to the water stress and slow production of photosynthates that regularly occurred during dry spells. However, the CP content of browse species remained above $100 \mathrm{~g} / \mathrm{kg}$ DM in $P$. dulce and L. acapulcencis in the DS, suggesting the possibility that leaves may be used as a DS fodder and/or as a feed supplement to low quality diets.

However, the variation in the chemical composition of our tree species has been observed in other studies with shrubs and tree species (Salem et al., 2007; Mbugua et al., 2008). The high CP content of $P$. dulce and L. acapulcencis was similar to those of other high quality shrubby forages such as Calycotum villosa (Gasmi-Boubaker et al., 2005). CP content per se should not be the sole criteria of judging the relative importance of a particular feedstuff. The difference in CP content between species may be due to inherent characteristics of each species related to their ability to extract and accumulate nutrients from the browse living conditions of soil and atmospheric N during the DS and RS. Other factors causing variation in the chemical composition of browse forages include planting location, part of plant, age of leaf and season. With regard to location, some authors have reported that browse plants in arid zones have higher $\mathrm{N}$ than plants in humid zones (Rittner and Reed, 1992; Salem, 2005). These differences determine the value of browse plant foliages as forages for ruminants. However, all of our browse species, in general, would have been able to meet the energy requirements of livestock at maintenance, and often higher (Le Houerou, 1980).

The differences among browses in NDFom and ADFom contents found in our study are consistent with Khanal and Subba (2001) and Salem et al. (2007). In the current study, the ADF/NDF proportion was highest for L. acapulcencis (mean: 0.85), lowest for Q. Laeta (0.67) and P. dulce had the intermediate (0.75). For all samples, the ADFom fraction is a large proportion of the NDFom, and high content of cellulose, lignin and lower levels of hemicellulose (Abdulrazak et al., 2000).

The digestive utilization of nitrogenous compounds depends on the presence of tannins and other phenolic compounds (Woodward and Reed, 1989; Rittner and Reed, 1992) or together with other secondary compounds such saponins or alkaloids 
Table 3

Correlation coefficients $(r)$ between chemical composition, condensed tannins fractions contents with the in vitro ruminal fermentation parameters, ME, OMD96 and PF of the tree species with ruminal inoculum of cow and goats.

\begin{tabular}{|c|c|c|c|c|c|c|c|}
\hline & $\mathrm{CP}$ & NDF & ADF & Free-CT & PCT & FCT & TCT \\
\hline GP96, Cow & $0.59^{* * *}$ & $-0.85^{* * *}$ & $-0.90^{* * *}$ & $-0.66^{* * *}$ & $-0.84^{* * *}$ & $0.44^{* *}$ & $-0.76^{* * *}$ \\
\hline GP96, UG & $0.52^{* *}$ & $-0.82^{* * *}$ & $-0.92^{* * *}$ & $-0.70^{* * *}$ & $-0.89^{* * *}$ & $0.35^{* *}$ & $-0.81^{* * *}$ \\
\hline GP96, AG & $0.53^{* * *}$ & $-0.88^{* * *}$ & $-0.93^{* * *}$ & $-0.64^{* * *}$ & $-0.82^{* * *}$ & $0.39^{* *}$ & $-0.74^{* * *}$ \\
\hline$b$, cow & $0.41^{* *}$ & $-0.70^{* * *}$ & $-0.88^{* * *}$ & $-0.74^{* * *}$ & $-0.95^{* * *}$ & $0.20^{\mathrm{ns}}$ & $-0.86^{* * *}$ \\
\hline$b, \mathrm{UG}$ & $0.48^{* *}$ & $-0.74^{* * *}$ & $-0.89^{* * *}$ & $-0.69^{* * *}$ & $-0.88^{* * *}$ & $0.32^{\mathrm{ns}}$ & $-0.80^{* * *}$ \\
\hline$b, \mathrm{AG}$ & $0.48^{* *}$ & $-0.80^{* * *}$ & $-0.92^{* * *}$ & $-0.69^{* * *}$ & $-0.87^{* * *}$ & $0.32^{\mathrm{ns}}$ & $-0.79^{* * *}$ \\
\hline$c$, cow & $0.83^{* * *}$ & $-0.54^{* * *}$ & $-0.35^{* *}$ & $-0.33^{* *}$ & $-0.24^{\mathrm{ns}}$ & $0.79^{* * *}$ & $-0.29^{\mathrm{ns}}$ \\
\hline$c, A G$ & $0.47^{* *}$ & $-0.75^{* * *}$ & $-0.49^{* *}$ & $-0.27^{\mathrm{ns}}$ & $-0.30^{\mathrm{ns}}$ & $0.38^{* *}$ & $-0.29^{\mathrm{ns}}$ \\
\hline$L$, cow & $-0.32^{\mathrm{ns}}$ & $0.39^{* *}$ & $0.38^{* *}$ & $0.15^{\text {ns }}$ & $0.22^{\text {ns }}$ & $-0.40^{* *}$ & $0.18^{\text {ns }}$ \\
\hline$L, \mathrm{UG}$ & $0.48^{* *}$ & $-0.06^{\mathrm{ns}}$ & $-0.23^{\mathrm{ns}}$ & $-0.71^{* * *}$ & $-0.49^{* *}$ & $0.16^{\text {ns }}$ & $-0.64^{* * *}$ \\
\hline$L, \mathrm{AG}$ & $-0.13^{\mathrm{ns}}$ & $0.52^{* *}$ & $0.20^{\mathrm{ns}}$ & $-0.17^{\mathrm{ns}}$ & $-0.17^{\mathrm{ns}}$ & $-0.22^{\mathrm{ns}}$ & $-0.18^{\mathrm{ns}}$ \\
\hline SCFA, cow & $0.78^{* * *}$ & $-0.82^{* * *}$ & $-0.77^{* * *}$ & $-0.62^{* * *}$ & $-0.70^{* * *}$ & $0.66^{* * *}$ & $-0.67^{* * *}$ \\
\hline SCFA,UG & $0.54^{* *}$ & $-0.89^{* * *}$ & $-0.93^{* * *}$ & $-0.65^{* * *}$ & $-0.85^{* * *}$ & $0.41^{*}$ & $-0.76^{* * *}$ \\
\hline SCFA,AG & $0.60^{* *}$ & $-0.91^{* * *}$ & $-0.90^{* * *}$ & $-0.61^{* * *}$ & $-0.76^{* * *}$ & $0.46^{* *}$ & $-0.70^{* * *}$ \\
\hline ME, cow & $0.87^{* * *}$ & $-0.73^{* * *}$ & $-0.68^{* * *}$ & $-0.65^{* * *}$ & $-0.66^{* * *}$ & $0.75^{* * *}$ & $-0.67^{* * *}$ \\
\hline $\mathrm{ME}, \mathrm{AG}$ & $0.76^{* * *}$ & $-0.84^{* * *}$ & $-0.80^{* * *}$ & $-0.66^{* * *}$ & $-0.73^{* * *}$ & $0.61^{* * *}$ & $-0.71^{* * *}$ \\
\hline OMD96, cow & $0.65^{* * *}$ & $-0.92^{* * *}$ & $-0.88^{* * *}$ & $-0.63^{* * *}$ & $-0.78^{* * *}$ & $0.50^{* *}$ & $-0.71^{* * *}$ \\
\hline OMD96, UG & $0.59^{* * *}$ & $-0.87^{* * *}$ & $-0.91^{* * *}$ & $-0.69^{* * *}$ & $-0.86^{* * *}$ & $0.43^{* *}$ & $-0.79^{* * *}$ \\
\hline OMD96, AG & $0.59^{* * *}$ & $-0.91^{* * *}$ & $-0.90^{* * *}$ & $-0.63^{* * *}$ & $-0.78^{* * *}$ & $0.45^{* *}$ & $-0.71^{* * *}$ \\
\hline PF, cow & $-0.28^{\mathrm{ns}}$ & $0.24^{\mathrm{ns}}$ & $0.51^{* *}$ & $0.50^{* *}$ & $0.62^{* * *}$ & $-0.16^{\mathrm{ns}}$ & $0.58^{* *}$ \\
\hline PF, UG & $0.57^{* *}$ & $-0.89^{* * *}$ & $-0.81^{* * *}$ & $-0.58^{* *}$ & $-0.72^{* * *}$ & $0-40^{*}$ & $-0.66^{* * *}$ \\
\hline $\mathrm{PF}, \mathrm{AG}$ & $0.18^{\mathrm{ns}}$ & $-0.39^{*}$ & $-0.12^{\mathrm{ns}}$ & $0.03^{\text {ns }}$ & $0.00^{\mathrm{ns}}$ & $0.12^{\mathrm{ns}}$ & $0.02^{\text {ns }}$ \\
\hline
\end{tabular}

UG; unadapted goats, AG; adapted goats; GP96: cumulative gas production at $96 \mathrm{~h}$; $b$ : asymptotic gas production (ml/g DM); $c$ fractional rate of gas production $\left(\mathrm{h}^{-1}\right)$; $L$ : lag time $(\mathrm{h})$; SCFA: short chain fatty acid concentration (mmol); ME: metabolisable energy content (MJ/kg DM); OMD96: truly organic matter disappearance at $96 \mathrm{~h}$; PF: partitioning factor (OM disappearance (OMD96)/total gas production (GP96). ns: no significant.

*** $\mathrm{P}<0.001$.

${ }^{* *} \mathrm{P}<0.01$.

$\mathrm{P}<0.05$.

(Salem et al., 2006; Mbugua et al., 2008), commonly present in some browse species. Higher secondary compound levels, in particular free-CT, in L. acapulcencis may prevent its use in this way, if the nutrients cannot be digested and utilized as fodder for animals. In contrast, the higher CP content in $P$. dulce, with its low TCT and its fractions (free-CT, PCT, FCT), during both seasons suggest it may be a better quality feed for ruminants than other browses. Values of TCT exceeding $50 \mathrm{~g} / \mathrm{DM}$ (i.e., L. acapulcencis) could inhibit microbial activity, depress DMD (Kumar and Vaithiyanathan, 1990) and reduce voluntary intake (Waghorn et al., 1990). Q. Laeta and P. dulce had relatively low levels of total and free-CT and may have other means of defense from herbivores, such as accumulation of cutin ( $Q$. Laeta) or physical defenses such as thorns ( $P$. dulce). Low tannin contents in $Q$. Laeta and $P$. dulce may be beneficial to ruminants due to their effect in reducing rumen degradation of forage proteins, which can be digested post-ruminally (Barry, 1989). Because of its high CP, low lignin and low tannins, in vivo studies seem to be warranted to determine if $Q$. Laeta and $P$. dulce could be used as a $C P$ supplement in ruminant diets.

The overall increase in TCT in DS versus in RS was probably due to higher DS temperatures, and is consistent with Cabiddu et al. (2000) and Salem et al. (2006) who reported TCT contents of various browse species. It could reflect effects of high temperatures during the DS collection period on concentrations of tannins, which may change as the plant matures due to physiological changes.

\subsection{In vitro gas production and energy utilization of the tree leaves}

The widely variation among browse species in their fermentation of gas production, and efficiency and energy utilization mostly may be due to their variable nutrient and secondary compound contents (Salem et al., 2006, 2007; Mbugua et al., 2008). Chemical composition and in vitro fermentation and digestibility are largely affected by plant species, plant morphological fraction, environmental factors, and maturity stage (Salem, 2005; Chikagwa-Malunga et al., 2009; Mbugua et al., 2008).

The fermentation efficiency and energy utilization of the low and medium tannins contents of $P$. dulce and $Q$. laeta, respectively, during the DS, with the exception of $L$. acapulcencis of the high tannins contents were improved that may explained by their chemical nature and concentration of tannins that may be valuable to ruminants (Mueller-Harvey, 2006).

High gas production and fermentation efficiency (i.e., PF); and OMD of $P$. dulce and $Q$. laeta leaves during the DS suggest high extent and rate of feed fermentation with a high browse energy utilization (SCFA and ME). Variable gas production within fodder species could due to nature and proportion of fiber as well as tannins contents. Therefore, higher nutritive value of $P$. dulce and $Q$. laeta during the DS than $L$. acapulcencis could mostly explained by lower fiber fractions and/or ADF/NDF 


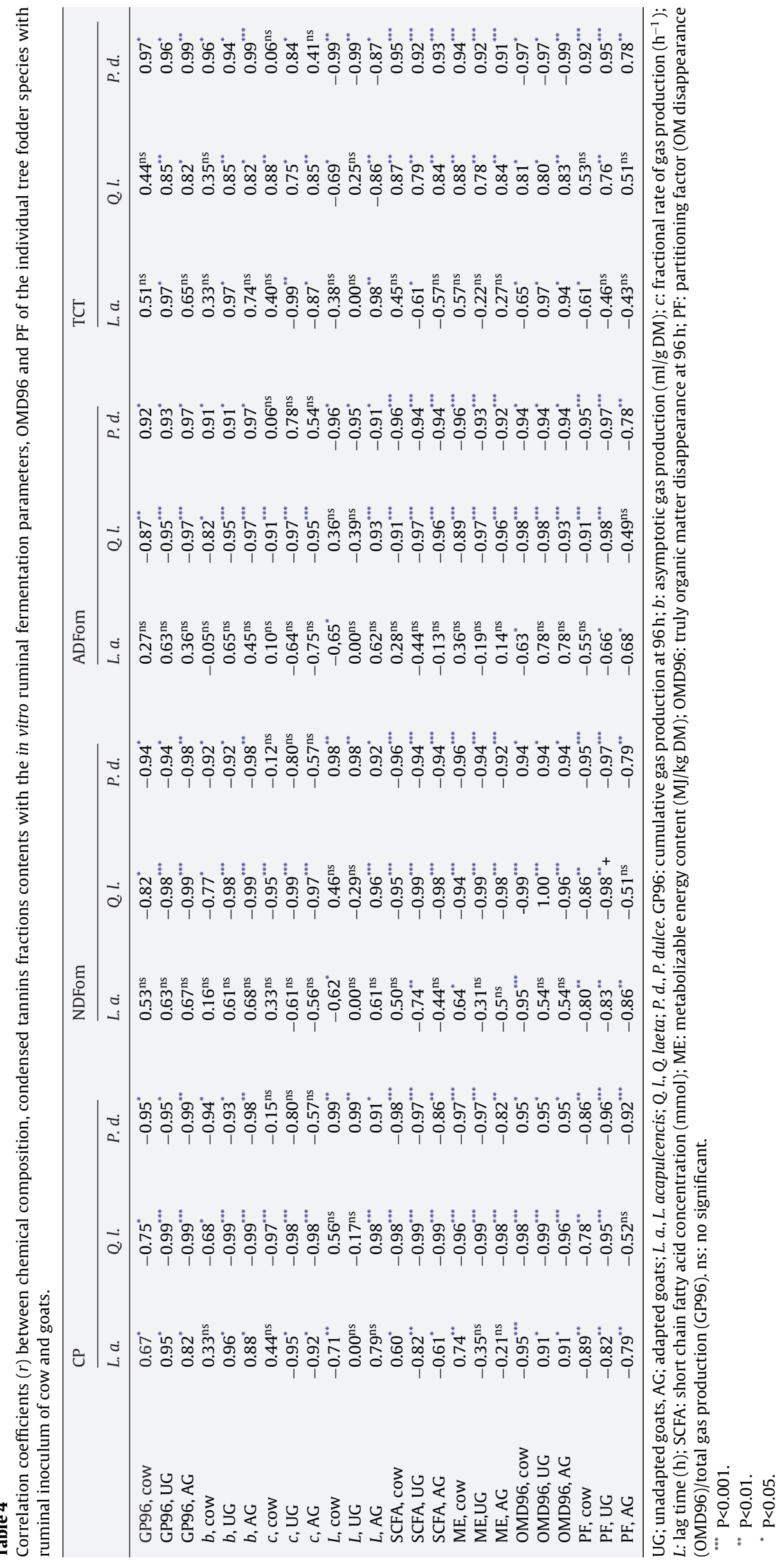


proportion ( 0.67 and 0.75 , respectively), and condensed tannins, in particularly free tannins than the L. acapulcencis of high fiber and tannins contents in DS (Tables 1 and 2).

The lower gas production and energy utilization of $L$. acapulcencis versus other browse species, overall and in particular during the DS, was probably due to higher extent of NDFom lignifications (Fonseca et al., 1998; Nordheim-Viken and Volden, 2009) and/or higher ADF/NDF proportion (0.85), and higher free-CT contents, which can reduce attachment of ruminal microbes to feed particles (McAllister et al., 1994), as well as inhibit microbial growth and enzyme activity (McSweeny et al., 2001) or intestinal bacterial activity (Salem et al., 2004) by free-condensed tannins. Getachew et al. (2000) and Salem et al. (2007) reported a decrease in rate and extent of gas production of some shrubs due to their high contents of lignin and tannins. Reductions of in vitro rumen fermentation of the high tannin browse (i.e., L. acapulcencis) may be due to the stronger influence of tannins on protein than on CP and DM degradability (Getachew et al., 2008). Free-CT may cause a strong depressing effect on microbial activity from in vitro gas production (Salem et al., 2007; Mbugua et al., 2008) and on efficiency of microbial growth (Salem et al., 2007; Getachew et al., 2008; Mbugua et al., 2008). Cellulolytic bacteria appear to be highly tannin-sensitive and, thus, tannins have a detrimental effect on in vitro and in situ fiber degradation (Salawu et al., 1997; Hervás et al., 2003).

This also could be explained by the negative relationship between the in vitro fermentation parameters, PF and energy utilization with browse fiber fractions and tannins contents (Tables 3 and 4). Salem (2005) and Salem et al. (2007) also reported a negative correlation between secondary compounds and in vitro gas production and DM degradability of some browse tree species. Similar negative relationships occurred between NDF, lignin(sa) and phenolics with in vitro digestibility in some perennial grasses (Casler and Jung, 2006), and Tolera et al. (1997) found similar impacts of proanthocyanidins in some browse legumes. Our results are similar to Rubanza et al. (2003), who reported a negative relationship between chemical composition, and phenolic compounds, with in vitro degradability of legumes of in vitro incubation.

Differences in the rumen environment among animal species (i.e., cows and goats) may affect the microbial population and/or the activity of degrading enzymes; and fermentation kinetics (Table 2). Indeed, the few direct data comparing microbial populations in the rumen activity of cows and goats are not available. However, Prasad and Pradhan (1990) showed higher numbers of total, amylolytic and proteolytic bacteria, but lower protozoal counts in buffalo versus sheep rumen fluid, whereas sheep rumen fluid contained microbial $\mathrm{N}$ (i.e., precipitable in trichloroacetic acid) in higher concentrations than buffalo. Addition of cellulose degrading bacteria or anaerobic fungi isolated from rumen liquor of sheep to a culture of buffalo rumen fluid did not affect fiber digestibility (Sahu et al., 2003; Paul et al., 2004), showing that although some microbial species are host-specific (Sahu and Kamra, 2002), likely differences between buffaloes and sheep in their microbial populations do not have an effect on extent of feed degradation in the rumen.

The high gas production, fermentation efficiency and energy utilization of browse species with the rumen fluid of AG compared to other animals (i.e., cows and UG) could explained by the previous adaptation and consuming of the same browse a long 100 days before the experiment. This period is sufficient to manipulate the microbial environment of AG group to adapt and minimize detrimental effects of tannins (Salem et al., 2000), and to acclimatized the microbial system in the rumen to the browse scrubland forms as a very important element in the capacity of these goats to utilize efficiently high tannin tree leaves (Gilboa, 1996).

Similar results were reported by Tjakradidjaja et al. (2000), who observed that browse from high tannin plant species (i.e., Acacia or Caliandra) were only digested by goats naturally adapted to consumption of high tannin feedstuffs. This is consistent with our finding that adapted goats had enhanced fermentative activity in the rumen to degrade high tannin substrates, but this benefit was less evident with feedstuffs with lower concentrations of tannins.

\section{Conclusions}

The P. dulce and Q. laeta of the low and medium tannins and high CP contents in the dry season had the highest nutritive value of ruminal gas production and energy utilization for cows and goats. Higher the nutritive value of theses browse species during the dry season could explain the higher importance of those species in nutrition of grazing ruminants in semi-arid regions. In contrast, the higher tannins and lower CP contents of L. acapulcencis during the dry season affect negatively on its fermentation efficiency and energy utilization. Goats provisory browses adapted had a better ability to ferment the browse species than cows or UG.

\section{Acknowledgements}

This work was undertaken with funds from the Universidad Autónoma del Estado de México (project UAEM 2400/2007). Our gratitude also to the Mexican National Council for Science and Technology (Consejo Nacional de Ciencia y TecnologíaCONACYT) for the grant received by Luis Miguel Camacho Díaz. Also, the authors thank Andrés Lee for his assistance in tannins analysis.

\section{References}

Abdulrazak, S.A., Fujihara, T., Ondiek, J.K., Ørskov, E.R., 2000. Nutritive evaluation of some Acacia tree leaves from Kenya. Anim. Feed Sci. Technol. 85, 89-98. AOAC, 1990. Official Methods of Analysis, vol. II., 15th ed. Association of Official Analytical Chemists, Arlington, VA, USA. 
Asquith, T.N., Butler, L.G., 1985. Use of dye-labeled protein as spectrophotometric assay for protein precipitans such as tannin. J. Chem. Ecol. 11, 1535-1544. Barry, T.N., 1989. Condensed tannins: their role in ruminant protein and carbohydrate digestion and possible effects upon the rumen ecosystem. In: Nolan, J.V., Leng, R.A., Demeyer, D.I. (Eds.), The Roles of Protozoa and Fungi in Ruminant Digestion. Pernambul Books, Armidale, NSW, Australia, pp. 153-167.

Blümmel, M., Steingss, H., Becker, K., 1994. The partitioning of in vitro fermentation and its bearing for the prediction of voluntary feed intake. Proc. Soc. Nutr. Physiol. 3, 123-127.

Blümmel, M., Steingss, H., Becker, K., 1997. The relationship between in vitro gas production, in vitro microbial biomass yield and $15 \mathrm{~N}$ incorporation and its implications for the prediction of voluntary feed intake of roughages. Br. J. Nutr. 77, 911-921.

Cabiddu, A., Decandia, M., Sitiza, M., Molle, G., 2000. A note on the chemical composition and tannin content of some Mediterranean shrubs browsed by Sarda goats. OPTIONS Méditerranéennes 52, 175-178.

Calabró, S., Williams, B.A., Piccolo, V., Infascelli, F., Tamminga, S., 2004. A comparison between buffalo (Bubalus bubalis) and cow (Bos taurus) rumen fluids in terms of the in vitro fermentation characteristics of three fibrous feedstuffs. J. Sci. Food Agric. 84, 645-652.

Casler, M.D., Jung, H.J., 2006. Relationships of fibre, lignin, and phenolics to in vitro fibre digestibility in three perennial grasses. Anim. Feed Sci. Technol. $125,151-161$

Chikagwa-Malunga, S.K., Adesogan, A.T., Salawu, M.B., Szabo, N.J., Littell, R.C., Kim, S.C., Phatak, S.C., 2009. Nutritional characterization of Mucuna pruiriens. 2. In vitro ruminal fluid fermentability of Mucuna pruriens, Mucuna l-dopa and soybean meal incubated with or without l-dopa. Anim. Feed Sci. Technol. $148,51-67$.

Evitayani, Warly, L., Fariani, A., Ichinohe, T., Abdulrazak, S.A., Fujihara, T., 2004. Comparative rumen degradability of some legume forages between wet and dry season in West Sumatra, Indonesia. Asian-Aust. J. Anim. Sci. 17, 1107-1111.

Fonseca, A.J.M., Dias-da-Solva, A.A., Ørskov, E.R., 1998. In sacco degradation characteristics as predictor of digestibility and voluntary intake of roughages by manure ewes. Anim. Feed Sci. Technol. 72, 205-219.

France, J., Dijkstra, J., Dhanoa, M.S., López, S., Bannink, A., 2000. Estimating the extent of degradation of ruminant feeds from a description of their gas production profiles observed in vitro: derivation of models and other mathematical considerations. Br. J. Nutr. 83, 143-150.

García, E., 1987. Modificaciones al sistema de clasificación climática de Koeppen. Universidad Nacional Autónoma de México, México, p. 246.

Gasmi-Boubaker, A., Kayouli, C., Buldgen, A., 2005. In vitro gas production and its relationship to in situ disappearance and chemical composition of some Mediterranean browse species. Anim. Feed Sci. Technol. 123-124, 303-311.

Getachew, G., Makkar, H.P.S., Becker, K., 2000. Tannins in tropical browses: effects on in vitro rumen fermentation and microbial protein synthesis in incubation medium containing different amount of nitrogen. J. Agric. Food Chem. 48, 3581-3588.

Getachew, G., Makkar, H.P.S., Becker, K., 2002. Tropical browses: contents of phenolic compounds, in vitro gas production and stoichiometric relationship between short chain fatty acid and in vitro gas production. J. Agric. Sci. 139, 341-352.

Getachew, G., Pittroff, W., Putnam, D.H., Dandekar, A., Goyal, S., DePeters, E.J., 2008. The influence of addition of gallic acid, tannic acid, or quebracho tannins to alfalfa hay on in vitro rumen fermentation and microbial protein synthesis. Anim. Feed Sci. Technol. 140, 444-461.

Gilboa, N., 1996. The negative effects of tannins and it's neutralization in livestock. Ph.D. Thesis, The Hebrew University of Jerusalem.

Hedqvist, H., Mueller-Harvey, I., Reed, J.D., Krueger, C.G., Murphy, M., 2000. Characterization of tannins and in vitro protein digestibility of several Lotus corniculatus varieties. Anim. Feed Sci. Technol. 87, 41-56.

Hervás, G., Frutos, P., Giráldez, F.J., Mantecón, A.R., Del Pino, M.A., 2003. Effect of different doses of quebracho tannins extract on rumen fermentation in ewes. Anim. Feed Sci. Technol. 109, 65-78.

Jones, G.A., McAllister, T.A., Muier, A.D., Cheng, K.J., 1994. Effects of sainfoin (Orobrychis viciifolia Scop.) condensed tannins on growth and proteolysis by four strains of ruminal bacteria. Appl. Environ. Microbiol. 60, 1374-1378.

Khanal, R.C., Subba, D.B., 2001. Nutritional evaluation of leaves from some major fodder trees cultivated in the hills of Nepal. Anim. Feed Sci. Technol. 92, $17-32$.

Kumar, R., Vaithiyanathan, S., 1990. Occurrence, nutritional significance and effect on animal productivity of tannins in tree leaves. Anim. Feed Sci. Technol. $30,21-38$

Le Houerou, H.N. 1980. Chemical composition and nutritive value of browse in West Africa. In: Le Houerou, H.N. (Ed.), Browse in Africa. ILCA, Addis Ababa.

Leng, R.A., 1997. Tree foliage in ruminant nutrition. FAO Animal Production and Health Paper 139. FAO, Rome, Italy.

López, J., Tejada, I., Vázquez, C., De Dios, G., Shimada, A., 2004. Condensed tannins in humid tropical fodder crops and their in vitro biological activity. Part 1. J. Sci. Food Agric. 84, 295-299.

Makkar, H.P.S., Singh, B., 1991. Distribution of condensed tannins (proanthocyanidins) in various fractions of young and mature leaves of some oak species. Anim. Feed. Sci. Technol. 32, 253-260.

Mangan, J.L., 1988. Nutritional effects of tannins in animal feeds. Nutr. Res. Rev. 1, 209-231.

Mauricio, R.M., Mould, F.L., Dhanoa, M.S., Owen, E., Channa, K.S., Theodorou, M.K., 1999. A semi-automated in vitro gas production technique for ruminant feedstuff evaluation. Anim. Feed Sci. Technol. 79, 321-330.

Mbugua, D.M., Kiruiro, E.M., Pell, A.N., 2008. In vitro fermentation of intact and fractionated tropical herbaceous and tree legumes containing tannins and alkaloids. Anim. Feed Sci. Technol. 146, 1-20.

McAllister, T.A., Bae, H.D., Jones, G.A., Cheng, K.J., 1994. Microbial attachment and feed digestion in the rumen. J. Anim. Sci. 72, $3004-3018$.

Menke, K.H., Steingass, H., 1988. Estimation of the energetic feed value obtained from chemical analyses and in vitro gas production using rumen fluid. Anim. Res. Dev. 28, 7-55.

Mould, F.L., Kliem, K.E., Morgan, R., Mauricio, R.M., 2005. In vitro microbial inoculum: a review of its function and properties. Anim. Feed Sci. Technol. $123-124,31-50$.

Mueller-Harvey, I., 2006. Unravelling the conundrum of tannins in animal nutrition and health. J. Sci. Food Agric. 86, $2010-2037$.

Nordheim-Viken, H., Volden, H., 2009. Effect of maturity stage, nitrogen fertilization and seasonal variation on ruminal degradation characteristics of neutral detergent fibre in timothy (Phleum pratense L.). Anim. Feed Sci. Technol. 149, 30-59.

Norton, B.W., 2000. The significance of tannins in tropical animal production. In: Brooker, J.D. (Ed.), Tannin in Livestock and Human Nutrition, vol. 92. ACIAR, Adelaide, Australia, pp. 160-164.

Paterson, R.T., Karanja, G.M., Roothaert, R.L., Nyaata, O.Z., Kariuki, I.W., 1998. A review of tree fodder production and utilization within smallholder agroforestry systems in Kenya. Agroforest. Syst. 41, 181-199.

Paul, S.S., Kamra, D.N., Sastry, V.R.B., Sahu, N.P., Agarwal, N., 2004. Effect of anaerobic fungi on in vitro feed digestion by mixed rumen microflora of buffalo. Reprod. Nutr. Dev. 44, 313-319.

Porter, L.J., Hrstich, L.N., Chan, B.G., 1986. The conversion of proanthocyanidins and prodelphinidins to cyanidins and delphinidin. Phytochemistry 25 , 223-230.

Prasad, D., Pradhan, K., 1990. Relative concentration of protozoa, bacteria and some enzymes in the rumen of cattle, buffalo and sheep fed various strawconcentrate diets. Indian J. Anim. Sci. 60, 576-581.

Rittner, U., Reed, J.D., 1992. Phenolics and in vitro degradability of protein and fiber in West African browse. J. Sci. Food Agric. 58, 21-28.

Robinson, P.H., Wiseman, J., Udén, P., Mateos, G., 2006. Some experimental design and statistical criteria for analysis of studies in manuscripts submitted for consideration for publication. Anim. Feed Sci. Technol. 129, 1-11.

Rubanza, C.D.K., Shem, M.N., Otsyina, R., Ichinohe, T., Fujihara, T., 2003. Nutritive evaluation of some browse tree legume foliages native to semi-arid area in western Tanzania. Asian Aust. J. Anim. Sci. 16, 1429-1437.

Sahu, N.P., Kamra, D.N., 2002. Microbial eco-system of the gastro-intestinal tract of wild herbivorous animals. J. Appl. Anim. Res. 21, 207-230.

Sahu, N.P., Kamra, D.N., Paul, S.S., 2003. Effect of cellulose degrading bacteria isolated from wild and domestic ruminants on in vitro dry matter digestibility of feed and enzyme production. Asian-Aust. J. Anim. Sci. 17, 199-202 
Salawu, M.B., Acamovic, T., Stewart, C.S., Hovell, F.D., 1997. Quebracho tannins with or without Browse Plus (a commercial preparation of polyethylene glycol) in sheep diets: effect on digestibility of nutrients in vivo and degradation of grass hay in sacco and in vitro. Anim. Feed Sci. Technol. $69,67-78$.

Salem, A.Z.M., 2005. Impact of season of harvest on in vitro gas production and dry matter degradability of Acacia saligna leaves with inoculum from three ruminant species. Anim. Feed Sci. Technol. 123-124, 67-79.

Salem, A.Z.M., González, J.S., López, S., Ranilla, M.J., 2000. The effect of feeding alfalfa treated with quebracho on parotid salivation in sheep. In: Van Arendonk, J.A.M. (Ed.), The 51st Annual Meeting of the European Association for Animal Production (EAAP), Session N5.17. Wageningen Press, August 21-24, The Hgue, The Netherlands, p. 152 (abstract).

Salem, A.Z.M., Gohar, Y.M., El-Adawy, M.M., Salem, M.Z.M., 2004. Growth-inhibitory effect of some antinutritional factors extracted from Acacia saligna leaves on intestinal bacteria activity in sheep. In: Proceedings of the 12th Scientific Conference of the Egyptian Society of Animal Production (ESAP), Mansoura, Egypt, pp. 283-300.

Salem, A.Z.M., Salem, M.Z.M., El-Adawy, M.M., Robinson, P.H., 2006. Nutritive evaluations of some browse tree foliages during the dry season: secondary compounds, feed intake and in vivo digestibility in sheep and goats. Anim. Feed Sci. Technol. 127, 251-267.

Salem, A.Z.M., Robinson, P.H., El-Adawy, M.M., Hassan, A.A., 2007. In vitro fermentation and microbial protein synthesis of some browse tree leaves with or without addition of polyethylene glycol. Anim. Feed Sci. Technol. 138, 318-330.

SAS Institute, 2002. SAS User's Guide: Statistics. Ver 9.0. SAS Institute, Cary, NC, USA, p. 956

Skarpe, C., Bergström, R., 1986. Nutrient content and digestibility of forage plants in relation to plant phenology and rainfall in the Kalahari, Bostwana. J. Arid Environ. 11, 147-164.

Steel, R.G.D., Torrie, J.H., 1980. Principles and Procedures of Statistics: A Biometrical Approach. McGraw-Hill Book Co., New York, p. 633.

Tefera, S., Mlambo, V., Dlamini, B.J., Dlamini, A.M., Koralagama, K.D.N., Mould, F.L., 2008. Chemical composition and in vitro ruminal fermentation of common tree forages in the semi-arid rangelands of Swaziland. Anim. Feed Sci. Technol. 142, 99-110.

Terrill, T.H., Rowan, A.M., Douglas, G.B., Barry, T.N., 1992. Determination of extractable and bound condensed tannin concentrations in forage plants, protein concentrate meals and cereal grains. J. Sci. Food Agric. 58, 321-329.

Theodorou, M.K., Williams, B.A., Dhanoa, M.S., McAllan, A.B., France, J., 1994. A simple gas production method using a pressure transducer to determine the fermentation kinetics of ruminant feeds. Anim. Feed Sci. Technol. 48, 185-197.

Tjakradidjaja, A.S., Brooker, J.D., Bottema, C.D.K., 2000. Characterisation of tannin-resistant bacteria from the rumen fluid of feral goats and camels with restriction analysis of amplified 16S rDNA. In: Brooker, J.D. (Ed.), Tannins in Livestock and Human Nutrition. Proceedings of an International Workshop held in Adelaide, Australia, Australian Center for International Agricultural Research (ACIAR). Canberra, pp. 161-165.

Tolera, A., Khazaal, K., Ørskov, E.R., 1997. Nutritive evaluation of some browse species. Anim. Feed Sci. Technol. 67, $181-195$.

Van Soest, P.J., Robertson, J.B., Lewis, B.A., 1991. Methods for dietary fiber, neutral detergent fiber and non-starch carbohydrates in relation to animal nutrition. J. Dairy Sci. 74, 3583-3597.

Waghorn, G.C., Jones, W.T., Shelton, I.D., McNabb, W.C., 1990. Condensed tannins and the nutritive value of herbage. Proc. NZ. Grassl. Assoc. 51, 171-176.

Waghorn, G.C., McNabb, W.C., 2003. Consequences of plant phenolic compounds for productivity and health of ruminants. Proc. Nutr. Soc. 62, 383-392.

Woodward, A., Reed, J.D., 1989. The influence of polyphenolics on the nutritive value of browse. A summary of research conducted at ILCA. ILCA Bull. (International Livestock Centre for Africa (ILCA), Addis Ababa, Ethiopia) 35, 2-11.

Yousef, E.M., Rouzbehan, Y., 2008. Characterization of Quercus persica, Quercus infectoria and Quercus libani as ruminant feeds. Anim. Feed Sci. Technol. 140, 78-89. 